\title{
TESES DE DOUTORADO
}

\section{3}




\section{CAMPOS, Heraldo Cavalheiro Navajas Sampaio}

Caracterização e cartografia das provincias hidrogeoquimicas do Estado de São Paulo. 31 de agosto. 177p. Orientador: Mária Szikszay.

Resumo: Os sistemas aquiiferos representam uma das principais fontes de suprimento de águas subterrâneas do Estado de Săo Paulo. Estăo representados por sistemas aquíferos sedimentares e sistemas aquíferos fraturados, de litologia variável, recobrindo uma área de $247.898 \mathrm{~km}^{2}$.

Em âmbito regional os objetivos deste estudo foram; a caracterização dos tipos hidrogeoquímicos e sua inter-relação; o estudo da evoluçāo da composiçăo química das águas subterrâneas com fluxo no meio aqüifero; a determinação da origem de anomalias hidrogeoquímicas; a determinaçăo da qualidade das águas para os distintos usos e a determinação do potencial de ataque químico das águas subterrâneas aos equipamentos dos poços.

Foram utilizadas neste trabalho 1.364 análises quimicas de águas subterrâneas de poços tubulares. A interpretaçäo dos dados hidrogeoquimicos baseou-se no processamento dos resultados das análises quimicas, em mapas de isovalores e em integração cartográfica.

As águas subterrâneas apresentam, em geral, teores salinos muito baixos e pertencem a dois tipos químicos dominantes: águas bicarbonatadas cálcicas e águas bicarbonatadas sódicas. A tendência principal da evoluçăo hidrogeoquimica regional é de nordeste para sudeste, no Sistema Aquifero Botucatu. A principal anomalia observada (F) tem sua origem sugerida pelos condicionantes estruturais.

Quanto à adequaçāo das águas subterrâneas para os distintos usos, de um modo geral, atendem aos padrōes de potabilidade vigentes; as águas são potencialmente incrustantes ou corrosivas ou potencialmente corrosivas.

Abstract: The aquifer systems stand for one of the main supplies of groundwater in the Săo Paulo State. It's represented by the aquifer sedimentary systems and the aquifer fractured systems with variable lithology, covering an area of $247.898 \mathrm{~km}^{2}$.

The hydrogeochemical studies carried out herewith, were intended to investigate, in a regional basis, the following topics: the characterization of the different hydrogeochemical types and their interrelations; the evolution of the groundwater's chemical composition along the percolation in the aquifer; the hydrogeochemical zoning and the discrimination of chemical types according to the hydrogeochemical anomaly; the determination of the water quality according to the different uses and its chemical attack potential to the well equipment.

In this study 1.364 groundwater chemical analyses were employed. The hydrogeochemical data interpretation was based on: data analyses processing, isovalues maps and cartographic integration.

The groundwater have, generally, a very low salinity content and belong to two dominant chemical types: the calcium bicarbonate type and the sodium bicarbonate type. The principal trend in the regional hydrogeochemical evolution according to ionic increase is from northeast to southwest (Botucatu aquifer system). The hydrogeochemical anomaly (F-) propose relationship with structural lineaments.

Concerning the groundwater chemical quality for the various uses these waters comply the required quality standards; the groundwater is incrusting or corrosive.

\section{GIANNINI, Paulo César Fonseca}

Sistemas deposicionais no quaternário costeiro entre Jaguaruna e Imbituba, SC. 12 de novembro. 439p. Orientador: Kenitiro Suguio. 
Resumo: Uma tentativa de análise conceitual da linguagem usada em tcoria de sistemas, aplicada à sedimentaçăo costeira quaternária, permitiu o reconhecimento e a descriçăo, em superficie, de quatro tipos de sistemas deposicionais na área do grande complexo lagunar centro-sul catarinense (lagoas Garopaba do Sul, Camacho, Santa Marta, Santo Antônio, Imaruí e Mirim). Sistema deposicional é definido como conjunto de fácies formadas por processos cm operaçăo conexa e organizada, possuindo assim padrão típico de arranjo espacial de fácies. Dos sistemas reconhecidos, dois estendem-se do Pleistoceno ao Holoceno: os sistemas élico e planicie costeira Os outros dois sistemas, lagunar e barra-barreira, săo considerados holocênicos.

Cada sistema deposicional é submetido a uma descrição externa $\mathrm{e}$ interna. A descrição externa trata das trocas de sedimentos e energia entre sistemas; estas trocas ocorrem sob dois modos diferentes, alternados no tempo: a retroalimentação (manutenção do estado estacionário de equilibrio) e os eventos de evolução espontânea (busca de novo estado estacionário). Exemplos de alternância entre mecanismos de troca são os ciclos de fechamento $c$ abertura da desembocadura lagunar do Camacho (canal de transferência entre os sistemas lagunar e barrabarreira) ou as fases de ativaçăo e cessamento de dunas eólicas primárias (relaçăo de troca entre a fácies praial dos sistemas barra-barreira ou planícic costeira e o sistema eólico). A descrição interna parte da concepção espaço-temporais de fácies, para cada sistema deposicional, e baseia-se na caracterização fisiográfica e sedimentológica (estruturas sedimentares, granulometria e minerais pesados) do sistema em diferentes níveis desta hierarquia. Detaca-se a subdivisão do sistema lagunar em duas associações de fácies, a baixio-laguna, gerada pelo afogamento transgressivo parcial de outros sistemas preexistentes,e a baía-laguna, formada por deposiçăo de uma barreira durante a transgressão iniciada no final do Pleistoceno. No sistema eólico, além de duas associą̧âes de fácies relacionadas a taxas de aporte sedimentar contrastantes, são reconhecidas pelo menos quatro geraçōes deposicionais. Supōem-se leis de dependência entre três fatores: os tipos de associaçôes de fácies, a morfoestratigrafia de geraçōes eólicas e o modo de interaçăo dinâmica (retroalimentação versus evoluçåo espontânea) entre sistema eólico e fácies praial. $\mathrm{O}$ último fator é controlado pelo comportamento do nível relativo do mar (NRM). Com base nisso, correlaçóes gerais entre geraçōes eólicas da área em estudo e de costas de padrăo de NRM similar em outros continentes săo propostas.

Abstract: An attempt of conceptual analysis of the language used in theory of systems applied to Quaternary coastal sedimentation, allowed the recognition and description, on surface, of four types of depositional systems in the area of the big lagoonal complex of southern-central Santa Catarina coast (Garopaba do Sul, Camacho, Santa Maria, Santo Antônio, Imarui and Mirim lagoons). Depositional system is defined as a set of facies formed by processes in connected and organized operation, having thus typical pattern of spatial arrangement of facies. Two of the recognized systems spread from Pleistocene to Holocene: the aeolian and strandplain systems. The other two systems, lagoon and barrier-bar, are considered as Holocene.

Each depositional system is submitted to an external and internal description. The external description concerns to exchanges of sediments and energy between systems; these exchanges occur through two different ways, alternated in the time: the feedback maintenance of the equilibrium steady state) and the events of spontaneous evolution (searching for a new steady state). Examples of alternance between mechanisms of exchange are the cycles of closing and opening of the Camacho lagoonal inlet (transfer channel between lagoon and barrier-bar systems) or the phases of activation and interruption of primary aeolian dunes (exchange relationship between the beach facies of barrier-bar and strandplain systems and the aeolian system). The internal description departs from the conception of spatial-temporal hierarchies of facies, for each depositional system, and bases itself on the physiographic and sedimentological characterization (sedimentary structures, grain size and heavy minerals) of systems in different levels of this hierarchy. It is outstanding the subdivision of the lagoon system into two associations of facies, the low-lagoon, generated by the partial transgressive drowning of other pre- 
existing systems, and the bay-lagoon, formed by deposition of a barrier during the transgression started at the end of Pleistocene. In the aeolian system, besides the two associations of facies related to contrasting rates of sedimentary supply, at least four deposit generations are recognized. It is supposed that there are laws of dependence between three factors: the types of associations of facies, the morphostratigraphy of aeolian generations and the way of dynamic interaction (feedback versus spontaneous evolution) between aeolian system and oceanic beach facies. The last factor is controlled by the behavior of the relative sea level (RSL). In that basis, general correlation between aeolian generations in the study area and of coasts of similar RSL pattern in other continents has been proposed.

\section{GONCALVES, Mônica Lopes}

Geologia para planejamento de uso e ocupação territorial do municipio de Joinville. 03 de dezembro. 73p. Orientador: Uriel Duarte.

Resumo: O municipio de Joinville constitui o maior polo industrial do Estado de Santa Catarina. Por outro lado, situa-se numa regiăo extrememente sensivel do ponto de vista fisiográfico-ambiental, face a apresentar aproximadamente $66 \%$ do seu território constituido por encostas e planalto da Serra do Mar, $29 \%$ por planícies sedimentares com morros isolados com larga presença de sedimentos de turfa e $5 \%$ por manguezais.

A presente tese de doutoramento demonstra a necessidade de se desenvolver um planejamento do uso e ocupaçăo do solo compativel com as caracteristicas fisicas da regiäo. Este planejamento tem como base o conhecimento geológico, facilitando na tomada de decisões e na previsăo orçamentária de projetos públicos e privados.

O conhecimento geológico, associado ao estudo da declividade, mostra as zonas que năo devem ser ocupadas devido à dificuldade, ou mesmo impossibilidade de implantaçăo de determinados projetos.

Um outro dado básico para o desenvolvimento urbano-industrial-agricola compativel com as características físicas da regiảo é o potencial hidrico, seja superficial ou subterrâneo.

A atividade minerária é fundamental para a construção civil, mas por outro lado deve ser excecutada com um minimo de efeito ambiental.

Os dados geológico-estruturais, geomorfológicos e hidrológicos foram reunidos em cartas temáticas a fim de fornecer informaçães para órgãos públicos e privados, auxiliando na tomada de decisōes sobre uso e ocupação territorial sobre o Município de Joinville.

Abstract: Joinville's county is the greatest industrial center in the state of Santa Catarina. However the county is located in an extremely sensitive region according to the physiographical environmental point of view. The region presents $66 \%$ of it's territory formed by high slopes and plateaus of "Serra do Mar", $29 \%$ is formed by sedimentary plains with isolated mountains with a large presence of turfe and sediments and $5 \%$ is formed by swamps.

The present doctorship thesis estates the necessity of the development of a planning in how to use and how to occupy the soil regarding the physical characteristics of the region. The base of this planning is the geological knowledge that provides easier and more suitable ways for the decision taken and the prediction of financial budget made by public and private projects.

The geological knowledge of the region, associated to the declivity study show zones that must not be occupied due to the difficulty or even total impermaint for the accomplishment of certain projects.

Another basic data for the urban-industrial-agricultural development compatible with the physical characteristics of the region is it's hydro potential either on the surface or in the underground. 
The mineral activity is fundamental for civil building. once is made affecting the environment the least.

The structural-geologic, geomorphologics and hydrologics datas were compounded in thematic charts to provide Public Agencies and Private enterprises with the information to help them in how to best implement the use and the occupation of the soil and territory of Joinville's county.

\section{HEILBRON, Mônica da Costa Pereira Lavalle}

Evoluçäo tectono-metamórfica da Seçao Bom Jardim de Minas (MG) - Barra do Pirai (RJ). Setor central da Faixa Ribeira. 30 de setembro. 268p. Orientador: Rômulo Machado.

Resumo: Na Seç̃o geotransversal Bom Jardim de Minas (MG) - Barra do Pirai (RJ), segmento central da Faixa Móvel Ribeira (FR), quatro escamas de empurrão, imbricadas de SE para NW, cavalgam o Domínio Tectônico Autóctone (DTA), situado na margem sul-sudeste do Cráton do Săo Francisco (CSF). O Dominio Tectônico Paraiba do Sul (DTPS) representa a escama superior e cavalga o Domínio Tectônico Juiz de Fora (DTJF) que, por sua vez, se superpõe aos terrenos dos Domínios Tectônicos Andrelândia Alóctone (DTAND) e Andrelândia Parautóctone (DTAP).

No DTAND foram identificados dois conjuntos litológicos: a) supracrustais do Proterozóico Médio, constituem o Ciclo Deposicional Andrelândia (CDA). Rochas metabásicas invadem - CDA e sua assinatura geoquímica é indicativa tanto para afinidade toleitica continental como para basaltos do tipo N-Morb; e b) seu embasamento constituido por ortognaisses tonalíticos, migmatiticos, intrudidos por granodioritos e granitos, e por rochas granulíticas. Este conjunto é denominado Complexo Mantiqueira (CM) e sua história geológica remonta ao Arqueano, com importante retrabalhamento e acresçăo crustais no Proterozóico Inferior.

O DTJF é caracterizado por uma intercalaçăo tectônica de dois conjuntos distintos: a) metassedimentos correlacionáveis ao CDA, com intrusōes de rochas metabásicas e idêntico empilhamento tectono-estratigráfico que o do DTAND; e b) granulitos ortoderivados, de composiçăo e características geoquimicas variadas, integrantes do Complexo Juiz de Fora (CJF).

No DTPS, ocorre o Grupo Paraiba do Sul (GPS), constituido por xistos e paragnaisses com intercalaçōes de rochas carbonáticas e calciossilicáticas, invadido pela Suite Intrusiva QuirinoDorândia (SIQD), composta por ortognaisses graníticos, monzoníticos e granodioriticos, de provável afinidade calcioalcalina.

Os três dominios tectônicos investigados em maior detalhe (DTAND, DTJF e DTPS) mostram a mesma evoluçăo metamórfica e deformacional, com diferenças em estilo estrutural e intensidade do metamorfismo atribuidas a distintos niveis crustais superpostos durante intenso encurtamento crustal. As fases da Deformação Principal $\left(D_{1}+D_{2}\right)$ săo responsáveis pelo imbricamento destas escamas de empurrāo. Compōem o quadro da Deformaçāo Principal: dobras apertadas a isoclinais, assimétricas, acilindricas, associadas à foliação penetrativa $\left(\mathrm{S}_{2}\right.$ ou $\left.\mathrm{S}_{1}+\mathrm{S}_{2}\right)$; dobras em bainha e tubulares; zonas de cisalhamento com formaçăo de rochas miloniticas; e forte lineaçăo de estiramento. A análise estrutural geométrica permitiu a visualizaçăo de um modelo cinemático evolutivo, tipico para áreas de convergência obliqua: na etapa $\mathrm{D}_{1}$ a cedo- $\mathrm{D}_{2}, 0$ transporte tectônico principal é para $\mathrm{NW}$, em direção ao CSF; 0 intenso encurtamento causa a verticalização das estruturas já formadas e a incorporação de lascas do embasamento; na etapa tardi- $\mathrm{D}_{2}$, a deformaçäo principal passa a possuir um importante componente direcional dextral, especialmente no contato do DTPS com o DTJF. Nesta última etapa é ativado o empurrão basal do DTAND, pós-ápice tértmico, resultando em perturbaçōes no padrăo metamórfico previamente estabelecido.

Após a compartimentaçåo tectônica causada pela deformação principal, os três domínios experimentam os efeitos das fases de deformação tardias $\left(D_{3} \in D_{4}\right)$. A deformaçăo $D_{3}$ ainda é típica para ambientes compressivos, e origina o redobramento das estruturas já formadas, com planos axiais 
subverticais e eixos de caimento suave NE-SW. A estrutura de dobramento $\mathrm{D}_{3}$ observada de escala regional, a Megassiforma do Rio Paraiba do Sul (MSPS), faz com que voltem a aflorar, no flanco SE (região da Serra do Mar), as escamas tectônicas observadas no flanco NW (Serra da Mantiqueira). O caráter heterogêneo de $\mathrm{D}_{3}$ origina importantes zonas de cisalhamento dúcteis transpressivas dextrógiras, como a do Rio Paraiba do Sul (ZCPS). $\mathrm{D}_{4}$ causa dobras suaves a abertas associadas a zonas de cisalhamento de direção $\mathrm{NNW}$, em regime dúctil-rúptil. A análise das componentes de rejeito e o giro anti-horário destas zonas de cisalhamento săo sugestivos para um regime de deformaçăo transtensiva.

Duas etapas metamórficas $\mathrm{M}_{1}$ e $\mathrm{M}_{2}$ estão associadas à tectônica convergente. A etapa $\mathrm{M}_{1}$, com ápice térmico sin- $\mathrm{D}_{2}$, possui regime de pressão intermediária a alta, e é responsável pelo padrão metamórfico inverso observado. A etapa $\mathrm{M}_{2}$ em regime de pressão mais baixa, é associada à deformaçăo $\mathrm{D}_{3}$ e à geraçáo de rochas granitóides do tipo $\mathrm{I} e \mathrm{~S}$, que invadem principalmente o DTPS. AS etapas $\mathrm{M}_{1}$ e $\mathrm{M}_{2}$ săo interpretadas como continuas e decorrentes de um processo de colisão continental: $\mathrm{M}_{1}$ é representante da época de deslaminação e underthrusting do DTAND, subductado para SE, por baixo do DTJF e DTPS; e $\mathrm{M}_{2}$ é resultante da duplicaçăo crustal com refusấo dos metassedimentos e de seu embasamento, na etapa tardicolisional.

A investigação litogeoquimica do CJF permitiu a individualização de quatro séries magmáticas distintas: a) Série Toleitica de Alto $\mathrm{TiO}_{2}$, enriquecida em elementos litófilos de raio iônico grande, típica para magmatismo basáltico intraplaca; b) Série Toleítica de baixo $\mathrm{TiO}_{2}$; c) Série Calcioalcalina; e d) Série Calcioalcalina de Alto $\mathrm{K}_{2} \mathrm{O}$. As três últimas apresentam caracteristicas geoquímicas de ambientes colisionais, e podem representar estágios diferentes na evolução de um arco magmático cordilherano.

A integração dos dados obtidos com os disponiveis na literatura permitiu a elaboração de um modelo de evoluçáo tectônica ensiálica para o setor central da FR investigado, com a implantaçăo de bacias intracontinentais no Proterozóico Médio, e por seu intenso encurtamento no Evento Termotectônico Brasiliano (Ett-B). Processos como deslaminação, underplating e subdução A (para SE) do segmento litosférico do DTAND sob o DTPS poderiam ser responsáveis pelos efeitos metamórfico-deformacionais e pelo magmatismo identificado na seçāo geotransversal. O DTJF representaria uma zona de sutura desta etapa de colisão obliqua, com intensa incorporação e retrabalhamento de segmentos crustais mais profundos.

Abstract: Detailed geological mapping combined with structural, metamorphic, geochemical and geochronological analysis were carried out at the Bom Jardim de Minas (MG) - Barra do Pirai (RJ) geotransect, Southeastern Brazil. These data led to a regional tectonic subdivision for the central segment of the Late Proterozoic (Brasiliano-Panafrican) Ribeira Belt (FR). Imbricated from SE to NW towards the southern and southeastern margin of Sao Francisco Craton (CSF), five tectonic domains were identified. From top to bottom, these are the following: a) The Paraiba do Sul Tectonic Domain (DTPS) is characterized by the Paraiba do Sul Group (GPS), a metasedimentary sequence with abundant carbonatic and calcsilicatic intercalations. This unit is intruded by calcalkaline granitoids with strong deformation (SIQD - Quirino-Dorândia Intrusive Suite). Orthogneisses and granulitic rocks probably constitute the basement of the GPS. b) The Juiz de Fora Tectonic Domain (DTJF) represents a terrain of tectonic mixing between metasediments of the Middle Proterozoic Andrelandia Depositional Cycle (CDA) and Early Proterozoic to Archacan orthogranulites of the Juiz de Fora Complex (CJF). c) The Andrelândia Allochthonous and Parautochthonous Tectonic Domains (DTAND and DTAP) are characterized by the CDA and basement rocks of the Mantiqueira Complex (a typical High Grade Terrain) and the Barbacena Complex (low grade Granite-Greenstone Terrain). d) The Autochthonous Tectonic Domain (DTA), bordering the CSF, is composed of the Andrelândia (CDA), Carandai (CDC). Lenheiro (CDL) and Tiradentes (CDT) metasedimentary depositional sequences. The latter two represent the rift phase, and are separated in time from the Carandai transgressive period by an erosional extensional period, with mafic dike emplacement. After a new erosional interval with 
exposition of basement rocks, the CDA transgressive sequence was deposited. Basement rocks in the DTA are similar to those in the DTAP and DTAND tectonic domains.

Thrust sheet stacking was achieved during $D_{1}+D_{2}$ deformation, responsible for the generation of the most important structures detected along the geotransect, such as: ductile shear zones with reverse and dextral components, asymmetrical recumbent to inclined folds, a penetrative $S_{2}$ foliation (with mylonitic character in the DTJF), stretching and mineral lineations, sheath and tubular folds. Differences in style and intensity of $D_{1}+D_{2}$ deformation are observed among the tectonic domains, and are attributed to different crustal levels. The geometrical analysis combined with the study of shear sense indicators allowed the following kinematic interpretation, characteristic of an oblique collision: a) $D_{1}$ to early- $D_{2}$ Phase- SE-NW compression produced thrusts, recumbent and sheath folds, refolding and incipient development of $S_{2}$ foliation; b) syn- $D_{2}$ Phase - as the compression continued early structures are verticalized and the deformation evolved to component with dextral lateral movement. The basal thrusts of DTJF and DTPS are activated at this stage. The former domain concentrated the effects of deformation; c) Late- $\mathrm{D}_{2}$ - the direction of tectonic transport became progressively more oblique causing reactivation of thrusts with a dextral directional component, especially at the contact between DTPS and DTJF. At this moment the basal thrust of DTAND is activated causing a metamorphic "jump" between this domain and the DTAP.

Two metamorphic stages, probably continuous in time, were identified in the metasedimentary sequences: a) $\mathrm{M}_{1}$ stage resulted in paragenesis of intermediate to high pressure, contemporary with the $\mathrm{D}_{1}+\mathrm{D}_{2}$ deformation. The metamorphic grade increases to the south, from the kyanite to the $\mathrm{K}$-feldspar zones; and b) syn- $\mathrm{D}_{3}$ deformation $\mathrm{M}_{2}$ stage generated high temperature-low pressure paragenesis with $\mathrm{I}$ and $\mathrm{S}$ type granitoid intrusions, especially located at antiformal structures. The $\mathrm{M}_{1}$ stage was probably associated with delamination and A-subduction of DTAND domain at the beginning of collision. The observed inverted metamorphic zonation emphasizes this interpretation. $M_{2}$ represents the post-collisional stage, with higher temperature gradient and extensive melting of duplicated crust.

A division of Juiz de Fora Complex in four magmatic series is proposed, based on lithogeochemical studies. The Medium and High $\mathrm{K}_{2} \mathrm{O}$ Calcalkaline and the $\mathrm{Low} \mathrm{TiO}_{2}$ Tholeiitic series are similar to igneous rocks of modern cordilleran magmatic arcs. The High-TiO $\mathrm{O}_{2}$ Tholeitic Series is enriched in LILE and specially in REE, characterizing an intraplate basaltic magmatism. Granulite facies metamorphism related to the Transamazonic tectono-thermal event (Early Proterozoic) affected all these series.

Finally, an ensialic tectonic evolution is envisaged for the Andrelandia Basin: a) Thermal relaxation following the Transamazonic Event induces the formation of Middle Proterozoic sedimentary basins, initially with a rift phase with mafic dykes (CDL e CDT), passing to an interior sag phase ( $C D C$ e $C D A)$; b) Delamination and A-subduction, probably associated with underplating, start to operate. Basic and minor ultrabasic intrusions, possibly along with volcanoclastic sediments, all derived from mantle underplating, reflect the final and more unstable stage of the Andrelândia Basin; c) As the subduction of DTAND proceeds, crustal shortening and tectonic incorporation of basement rocks $\left(D_{1}+D_{2}\right)$ are associated with the $M_{1}$ metamorphic stage (Brasiliano Event Ett-B); d) After collision, crustal duplication leads to extensive partial melting of CDA and its basement. The emplacement of I and $S$ type granitoids and the syn- $D_{3} M_{2}$ metamorphic stage characterize this tectonic period (Late Brasiliano Event).

\section{JULIANI, Cactano}

Geologia, petrogenese e aspectos metalogenéticos dos grupos Serra do ltaberaba e São Roque na regiäo das Serras do Itaberaba e da Pedra Branca, NE da Cidade de São Paulo, SP. 29 de abril. 803p. Orientador: Johann Hans Daniel Schorscher. 
Resumo: Os trabalhos desenvolvidos nesta tese tiveram, como principal objetivo, o estudo das rochas supracrustais dos grupos Serra do Itaberaba e São Roque, o relacionamento litoestratigráfico entre eles e a evoluçāo geológica dos litotipos, visando caracterizar parte da evoluçăo crustal do PréCambriano Paulista.

A área estudada situa-se a nordeste da Cidade de São Paulo, entre as Cidades de Guarulhos e Santa Isabel, e compreende cerca de $540 \mathrm{~km}^{2}$, mapeados na escala de 1:25.000, na qual foram mapeadas duas subáreas nas escalas 1:10.000 e 1:2.000 com, respectivamente, 41,5 e 2,6 km².

Diversos métodos de estudos foram adotados nesta pesquisa, incluindo, além dos mapeamentos geológicos, petrografia de rochas e minérios, através de seções delgadas e polidas, caracterização da composição das rochas graníticas, também através de análises modal em amostras com os feldspatos coloridos seletivamente, análise de minerais residuais, difratometria de raios $\mathrm{X}$ de minerais e rochas, petroquímica, análise estrutural macro- e microscópica e estudos metalogenéticos comparativos.

Os estudos permitiram caracterizar as rochas supracrustais como polideformadas e polimetamorfizadas, subdivisiveis nos grupos Serra do Itaberaba, mais antigo e basal, formado por sequêencias vulcano-sedimentar, clasto-química e clástica, denominadas, respectivamente de formaçöes Morro da Pedra Preta, Nhanguçu e Pirucaia, e Săo Roque, superior, essencialmente clástico, representado na área exclusivamente pela sua Formação Piragibu, aqui redefinida.

Durante 0 desenvolvimento da foliacalo $S_{1}$ do Grupo Serra do Itaberaba, foram geradas dobras isoclinais, em regime metamórfico do tipo Barrowiano, de grau predominantemente da fáceis anfibolito médio, com variaçbes locais para fäceis dos xistos verdes superior e anfibolito superior, com condiçōes máximas à $\mathrm{P} \approx 5-6 \mathrm{~kb} \mathrm{e} \mathrm{T} \approx 620^{\circ} \mathrm{C}$. O evento associado ao desenvolvimento da $\mathrm{S}_{2}$, com dobras isoclinais a similares fechadas, foi de intensidade próxima ao anterior, mas de pressáo mais baixa, sem cristalização da cianita. Este evento pode ser correlacionado ao que aconteceu quando do desenvolvimento da $S_{1}$ do Grupo Sáo Roque, da fácies dos xistos verdes. Eventos de crenulaçăo e retrometamórficos da fácies dos xistos verdes superimpuseram-se a estes.

Nota-se, de maneira geral, uma atenuação das deformaçōes e do metamorfismo das unidades basais para as de topo do Grupo Serra do Itaberaba e há, para ambos os grupos, aumento de grau metamórfico no sentido nordeste.

O metamorfismo de contato produzido pela intrusão das rochas graníticas foi verificado especialmente em áreas restritas, nas bordas dos Granitóides Serra da Pedra Branca, onde pode ter havido, inclusive, cristalização de granada e de estaurolita nos metapelitos da Formação Morro da Pedra Preta. Entretanto, de modo geral, as intrusóes causaram poucas e restritas alterações nas rochas supracrustais, indicando colocaçäo profunda dos corpos igneos.

Metamorfismo đinâmico em condiçōes đe P x T máximas compativeis com a fácies dos xistos verdes inferior a superior ocorreram generalizadamente ao longo das zonas de cisalhamento, que têm também frequientes rochas produzidas por reativação em temperaturas mais baixas.

Os metabasitos do Grupo Serra do Itaberaba incluem tipos com pillow lavas, indicando efusōes subaquáticas e neles puderam ser caracterizados processos de alteraçöes magmáticas, tais como fracionamento de olivina, piroxênios, plagioclásio e cromita e hidrotermais-metassomáticas de fundo oceânico, de variável intensidade, incluindo desde espilitos até rochas muito transformadas geradas em zonas de descarga de fluidos hidrotermais no fundo oceânico, que modificaram suas composiçōes químicas. Seus caracteristicos químicos permitiram classifica-los como tholeítos de fundo oceânico, gerados em segmentos normais (tipo $\mathrm{N}$ ) de cadeia meso-oceânica, com prováveis gradaçōes para zonas sob influência de plumas mantélicas (tipo E), possivelmente em ambiente geotécnico similar ao do tipo Golfo de Aden.

As rochas metaintermediárias foram geradas pela fusão da crosta oceânica, na sua subducção ensimática distante do arco de ilhas e do continente.

Rochas com cummingtonita, cordierita, granada, estaurolita, quartzo, biotita, clorita, 
plagioclásio e rutilo foram caracterizadas como produzidas a partir de vulcanitos e rochas vulcanoclásticas básicas por alteraçōes hidrotermais-metassomáticas causadas pela descarga em fundo oceânico de soluçōes vulcanogênicas, às quais associam-se mineralizaçbes de ouro.

As formaçōes ferriferas são do tipo Algoma c têm variável contribuição de rochas vulcano-clásticas e as rochas calciossilicáticas contaminaram, assim como os pelitos, parte das rochas metavulcano-clásticas.

Os manunditos foram caracterizados como gerados pela sobreposiçăo de vários processos, incluindo o retrabalhamento de rochas aluminosas geradas em zonas de atividade exalativa vulcanogênica, intemperismo e retrabalhamento mecânico subaquático e redeposição em bacias restritas ultra-salinas, geradas pelas soluç̋̈es hidrotermais vulcanogénicas.

Quanto aos metapelitos finos pôde-se sugerir origem a partir de um arco de ilhas e os mais grossos da Formação Pirucaia de áreas continentais, assim como os do Grupo São Roque. Influência de ambiente evaporítico pode ter ocorrido na Formação Nhanguçu, conforme indicam os metassedimentos (clásticos e vulcano-clásticos) ricos em aluminio, com argilas derivadas provavelmente de zonas de alteraçōes hidrotermais vulcanogênicas.

As rochas graníticas lato sensu foram separadas $\mathrm{em}$ duas suites, uma de rochas porfiriticas e outra não-porfiriticas, com tipos petrográficos incluindo granitos (3a e 3b), granodioritos, tonalitos, quartzo-dioritos, quartzo sienitos e quartzo monzonitos. Parte delas pode ter sido introduzida nas sequências supracrustais do Grupo Serra do Itaberaba em épocas mais antigas e alguns granodioritos e tonalitos muito alterados e deformados podem representar restos do embasamento siálico do Grupo Serra do Itaberaba. A quase totalidade das rochas é, entretanto, Brasiliana, dentre as quais se distinguem granodioritos um pouco mais velhos que os granitos e pequenas intrusōes tardias de granitos com muscovita e/ou granada e turmalina.

Zonas de cisalhamento e de falhas cortam as sequêencias, tendo gerado blastomilonitos, filonitos, milonitos e cataclasitos em periodos diversos, pré-cambrianos a, inclusive, cenozóicos.

Estes estudos incluem, ainda uma discussão preliminar dos tipos de mineralizações de ouro existentes nos grupos Serra do Itaberaba e São Roque, com comparaçбes entre elas, bem como do potencial metalogenético do Grupo Serra do Itaberaba para mineralizações de metais básicos.

Os trabalhos permitiram caracterizar a complexa evoluçấo crustal da regiăo, onde são bem individualizáveis os grupos São Roque e Serra do Itaberaba, mais provavelmente gerados em ciclos geotectônicos distintos, com idades minimas, o primeiro, no Proterozóico Médio-Inferior e, o segundo, talvez, no Proterozóico Superior.

Abstract: The main objective of this work is to characterize the crustal evolution of Precambrian terrains of a part of the State of São Paulo, particularly considering the lithostratigraphic relationships and the geological evolution of the supracrustal sequences of the Serra do Itaberaba and São Roque Groups.

The studied area is located between Guarulhos and Santa Isabel, northeast of the capital São Paulo, and covers $540 \mathrm{~km}^{2}$ that have been mapped on the scale 1:25,000. Two smaller areas of 41.5 and $2.6 \mathrm{~km}^{2}$ were mapped on the scales of $1: 10,000$ and $1: 2,000$, respectively.

Laboratory studies included rock and ore petrography (thin and polished sections), modal analysis of granitic rocks including selective staining of feldspars, analysis of residual minerals, $\mathrm{X}$-ray diffraction methods applied to the identification of minerals, rock geochemistry, macro- and microstrutural analysis and comparative metallogenesis of the Serra do Itaberaba and São Roque Groups.

The supracrustal rocks may be characterized as polydeformed and polymetamorphosed. The Serra do Itaberaba Group is older and basal and comprises sequences of volcanosedimentary, clastic-contaminated chemical and clastic rocks, respectively named the Morro da Pedra Preta, Nhanguçu and Pirucaia Formations. The overlying, younger São Roque Group is made up essentially of 
clastic rocks and represented in the area only by the Piragibu Formation (as redefined).

The $\mathrm{S}_{1}$ foliation of the Serra do Itaberaba Group was accompanied by isoclinal folding and Barrow-type regional metamorphism of mainly medium amphibolite facies grade; local variations ranged from upper greenschist to upper amphibolite facies. The maximum P-T conditions were estimated as $\mathrm{P} \approx 6 \mathrm{~kb}$ and $\mathrm{T} \approx 620^{\circ} \mathrm{C}$. The $\mathrm{S}_{2}$ foliation with isoclinal folding similar to the $\mathrm{S}_{1}$ folds developed under metamorphic conditions nearly as high as those of the previous event, however in a regime of lower pressure, without the crystallization of kyanite. This event caused the main metamorphism of the São Roque Group, of greenschist facies rank, and was accompanied by the development of the São Roque Group's $S_{1}$ foliation. Final events included superimposed crenulations and greenchist facies, retrograde metamorphism.

In the profiles of the Serra do Itaberaba Group, continuous deformational and metamorphic attenuations are evident from the bottom to the top of the unit. Both groups show increasing regional metamorphism towards the northeast.

Restricted contact metamorphism was produced by granitic intrusions, specially in the border zones of the Serra da Pedra Branca Granitoids, possibly augmenting garnet and staurolite formation in Morro da Pedra Preta metapelites. In general, however, the intrusions caused only weak and limited alterations in the supracrustal rocks indicating deep-sited intrusion of the granitoids.

Dynamic metamorphism under maximum P-T conditions of the greenschist facies was widespread in deeper parts of shear zones, and cataclastic rocks were produced under shallower crustal conditions.

Serra do Itaberaba Group metabasic rocks include pillow lavas indicating subaquatic eruptions. All the basic magmatic rocks suffered olivine, pyroxene, plagioclase and chromite fractionation in the magmatic stage and ocean-floor hydrothermal and metasomatic alteration of varied intensity producing spilites and very strongly transformed rocks in hydrothermal discharge zones.

The geochemical characteristics allowed the classification of the metabasic rocks a Ntype ocean-floor tholeites generated in normal segments of a mid-oceanic ridge with possible gradations to types formed under the influence of mantle plumes (E-type MORBs). Similarities exist with the geotectonic environment of the Gulf of Aden spreading center.

Metaintermediate rocks were formed by the fusion of oceanic crust in ensimatic subduction zones distant from island are and continental influences.

Rocks with cummingtonite, cordierite, garnet, staurolite, quartz, biotite, chlorite, plagioclase and rutile were identified as hydrothermal-metasomatic altered volcanics. They were produced by ocean-floor volcanogenic discharge solutions and are associated with gold mineralizations.

Algoma-type iron formations show varied contributions of volcanoclastic material and were partly contaminated by calc-silicate rocks and mudstones.

Manundites (margarite-corundum schists) were generated by the superposition of various processes including re-worked aluminous rocks from of volcanogenic exhalative zones, weathering, subaquatic mechanical re-working and redeposition in restricted ultrasaline basins, originated by volcanogenic hydrothermal solutions.

Island arc and continental origins are suggested, respectively, for the Pirucaia Formation and São Roque Group metapelites. Evaporitic influences may have occurred in the Nhanguçu Formation as indicated by aluminum-rich (clastic and volcanoclastic) sediments which contain clays derived most probably from zones of volcanogenic hydrothermal alteration.

Granitic rocks sensu lato were separated into two suites, one porphyritic and the other non-porphyritic. Both include $3 \mathrm{a}$ and $3 \mathrm{~b}$ granites, granodiorites, tonalites, quartz diorites, quartz syenites and quartz monzonites. Part of the bodies may have intruded the supracrustal sequences of the Serra do Itaberaba Group in earlier periods, and some strongly altered deformed granodiorites and tonalites may represent relics of a still older, pre-Serra do Itaberaba Group sialic basement. However, the overwhelming majority of the granitic rocks are of Brasiliano age, among which slightly older 
granodiorites may be separated from small, later, muscovite-and/or garnet - and tourmaline-bearing granite intrusions.

Shear and fold zones, in which blastomylonites, filonites, mylonites and cataclasites were generated, cut all the Precambrian rocks and were reactivated in different events, from Precambrian through Cenozoic times.

The preliminary metallogenic studies include a comparative discussion of the different types of gold mineralizations in the Serra do Itaberaba and Săo Roque groups and also a reappraisal of the Serra do Itaberaba Group base metal potential.

\section{NASCIMENTO, Nádia Regina de}

Sistemas de transformaçäo pedológica "solos lateriticos com couraça ferruginosa em silcrete e/ou planossolo": aplicaçăo à cartografia da pedomorfologia do médio vale do rio Paramirim - BA". 14 de setembro. 237p. Orientador: Adolpho José Melfi.

Resumo: Este trabalho trata do estudo das cobertas pedológicas no médio vale do Rio ParamirimBahia. Descreve, analisa e interpreta os dados de campo e de laboratório e identifica a distribuiçâo espacial da pedomorfologia, além de mostrar as relações entre as coberturas e a morfologia do relevo.

análises de laboratório.

A metodologia usada engloba estudos de campo, cartografia por sensores remotos e

Com este estudo chegou-se à identificaçđ̆o de dois sistemas de transformaçåo pedológica - "solos lateriticos com couraça ferruginosa em silcrete e/ou planossolo e silcrete em planossolo".

A partir da identificaçăo desses sistemas de transformaçăo pôde-se detectar as relaçōes entre as unidades de mapeamento, que indicaram a existência de sequêencias genéticas de evoluçăo da pedo-morfologia. Isto é, cada unidade mapeada representa uma etapa de evoluçâo tanto da cobertura pedológica como de relevo.

Com este estudo pôde-se evidenciar que:

- os solos largamente cartografados na regiăo, como latossolos, sảo, na verdade, reliquias de uma cobertura lateritica com couraça ferruginosa, cuja gênese se diferencia daquela dos latossolos;

- as coberturas detriticas, cartografadas como depósitos residuais de superficie de erosăo, såo na verdade coberturas pedológicas;

- essa cobertura lateritica está em desequilibrio com as condiçŏes pedobioclimáticas atuais, e, ocupava outrora, uma maior extensð̃o;

- o silcrete está em desequilibrio, embora, a presença de silica secundária na fase argilosa da cobertura planossólica, represente um enriquecimento dessa última, em silica;

- a distribuiçăo atual dos solos e do relevo é funçâo da evolução do sistema de transformação pedológica.

Abstract: This paper is about a research upon pedological mantles in the middle-valley of the Paramirim River in Bahia State - Brazil. It decribes, analyses and interprets field and laboratory data as well as it demonstrates relations between mantles and relief.

The adopted methodology comprehends field studies, remote sensing, cartographical and laboratory analyses.

It identifies two pedological transformation systems "ferricretes lateriticals soils to silcrete and/or planosoils". From this pedological transformation system it was possible to detecte relations amongst different mapping units that points out genetic pedo-morphological evolutions sequences. In other words, each mapping unit represents an evolution stage of pedological mantle as well as relief.

This study evidenced that: 
- the soils mostly mapped in the Paramirim Middle-Valley with "latossolos" are actually remains of a ferricrete lateritical soils which genesis is different from that of "latossolos":

- the detriticals mantles mapped with residual surface erosion deposits are pedological mantles;

- this ferricrete lateritical soils are in imbalance with presently pedo-bioclimatic conditions and it used to be more extensive in environment;

- the silcrete is in imbalance too although secondary silice in clay phase of planosolic mantle represents an enrichment in silice;

- the currently distribution of soils and relief is function of pedological transformation system evolution.

SOUZA FILHO, Edvard Elias de

Aspectos da geologia e estratigrafía dos depósitos sedimentares do rio Parand́ entre Porto Primavera (MS) e Guaira (PR). 21 de junho. 214p. Orientador: Paulo Milton Barbosa Landim.

Resumo: Este trabalho aborda o mapeamento geológico e a estratigrafia dos depósitos associados ao rio Paraná no segmento compreendido entre Porto Primavera (MS), a montante da foz do rio Paranapanema, e Guaira (PR), a jusante da foz do rio Piquiri.

A metodologia empregada para sua elaboração compreendeu as técnicas tradicionais de fotointerpretação geológica adaptadas para formas deposicionais, tendo sido utilizadas imagens MSS e RADAR, e fotografias aéreas. Os trabalhos de campo foram concentrados na metade superior do segmento estudado, no trecho situado a montante da ilha dos Bandeirantes; as informaçōes obtidas originaram-se de descriçöes de afloramentos, de sondagens a trado e a "vibro-core", e de perfis de sondagens fornecidos pela CESP e DALCON. Os dados foram analisados por meio de perfis topográficos, geológicos e estratigráficos, dispostos em posições perpendicular e longitudinal em relação ao traçado do rio.

Os depósitos estudados ocorrem em diferentes níveis de terraço e na calha fluvial. O terraço alto é constituído por níveis seixosos da sequêencia fluvial SFa, depositada por canais entrelaçados do tipo Scott, e por camada de areia maciça da sequêencia coluvial SCa. O terraço médio é constituido por niveis seixosos da sequiéncia fluvial SFb, depositados por canais entrelaçados do tipo Donjek; e por camada de areia maciça com ponds argilosos da sequeencia coluvial SCb. O terraço baixo é constituído por corpos de areia de forma acanalada ou tabular, da sequiência fluvial SFc, depositados por canais entrelaçados do tipo Platte. A planície fluvial corresponde ao terraço mais próximo do nível do rio, e compreende uma sucessāo de depósitos seixosos, arenosos e argilo-arenosos; esses sedimentos compreendem parte da sequéncia fluvial SFd, e foram depositados respectivamente por canais entrelaçados do tipo Donjek, do tipo Platte e por canais anastomosados. O terraço médio, o baixo e a planície encontram-se parcialmente cobertos por depósitos colúvio-aluviais da sequência SCc. Os depósitos ativos são constituidos por areia fina a média, acumulados no leito ou sob forma de barras transversais; tais corpos podem ocorrer no centro do canal, na sua margem, na parte frontal de ilhas, ou fazendo a ligaçâo entre ilhas e/ou as margens do rio. As caracteristicas hidrológicas do rio Paraná e de seus depósitos ativos permitem compará-los aos canais entrelaçados do tipo South Saskatchewan.

A evoluçăo sedimentar dos depósitos ocorreu por meio da alternância de climas úmidos e de climas secos, quando se desenvolveram respectivamente as sequiências fluviais e as coluviais. Durante esse período de tempo esteve ativa uma tectônica que promoveu basculamento e movimentação diferencial entre blocos estruturais, definidos por linhas e fraqueza ocupadas pelos principais elementos de drenagem. As correlaçōes efetuadas por meio de critérios geomorfológicos limitam os depósitos ao Pleistoceno e Holoceno, o uma correlaçăo com depósitos do rio Tibagi (PR) permite supor que a sedimentaçăo tenha-se iniciado pelo menos no Plioceno. 


\begin{abstract}
This research deals with geological mapping and stratigraphy of the Parana river deposits on the reach between Porto Primavera (MS) and Guaira (PR).

The geological mapping was based on MSS and RADAR image interpretation and aerial-photo analysis, besides field work in which outcrops and cores were analysed. Field work had been concentrated in the area between Porto Rico and Porto Camargo (PR). Additional data have been supplied by well records from CESP (Porto Primavera) and DALCON (Porto Camargo). The available data were analysed through longitudinal and transversal topographic profiles and geological and stratigraphic cross-sections.
\end{abstract}

The studied deposits occur in four different levels of terraces and in the active channel. The "high terrace" is constituted of gravel deposits of braided channel of Scott type (fluvial sequence $\mathrm{SF}$ a) covered with massive sands of colluvial sequence SCa. The "medium terrace" is constituted of gravel deposits of braided channel of Donjek type (fluvial sequence SFb) covered with massive sands and mud ponds of colluvial sequence $\mathrm{SCb}$. The "low terrace" is constituted of channel shape and tabular sand bed forms deposited by braided channel of Platte type. The fluvial plain is the lowest terrace and contains pebble deposits of Donjek braided channels covered with sand bed forms deposited by Platte braided channels which have been covered by mud and sand deposited in flood plain, channel and natural levee of anastomosed fluvial system. All the terraces may show alluvial fan and colluvial deposits covering parts of their surface (colluvial bars and lag deposits distributed in two levels into the channel). The hydrologic and faciologic present day characteristic of Paraná river enable us to compare them South Saskatchewan braided river.

The sedimentary deposits have developed through cyclic climatic changes (humid and dry phases) and under tectonic influence. During humid phases the fluvial systems were more active than the alluvial systems. On the other hand, in dry periods the situation was reverted. Tectonic events have tilted the block confined by fault structures and controlling the valley slope. According to geomorphological correlations the deposits are Quaternary in age, but palinological evidence suggests Pliocene age for the oldest deposits.

\title{
VALERIANO, Cláudio de Morisson
}

Evolução teciónica da extremidade meridional da Faixa Brasilia, região da represa de Furnas, sudoeste de Minas Gerais. 30 de abril. 192p. Orientador: Wilson Teixeira.

Resum0: Com base em levantamentos geológicos detalhados, integrados à escala de 1:100.000, é proposta uma subdivisão tectônica para a porçâo meridional da Faixa Brasilia (Proterozóico Superior), à borda SW do Cráton do São Francisco, região da represa de Furnas. A Nappe Araxá-Canastra (NAC) sobrepõe-se ao Sistema de Cavalgamento llicinea-Piumhi (SCIP), ambos empurrados sobre o domínio autóctone.

A NAC é constituída na base pelo Grupo Canastra, sobreposto gradacionalmente pelo Grupo Araxá. O primeiro apresenta uma sequeencia metassedimentar composta, da base para o topo, por: metapelitos e calcifilitos com lentes de mármore calcítico (unidade pelítico-carbonática); filitos sericiticos com intercalaçбes de quartzito (unidade psamo-pelítica inferior); quartzitos puros a micáceos com intercalaç̋̉es de sericita filito e muscovita xisto (unidade psamítica); e muscovita xistos com intercalaçôes de quartzito (unidade psamo-pelítica superior). Proporçôes crescentes de feldspato (e biotita) nos xistos do topo do Grupo Canastra marcam a sua graduação para o Grupo Araxá, que se inicia por paragnaisses bandados com níveis de biotita xisto, com quartzito e calcixisto subordinados. Em contraste à sedimentaçăo de plataforma (ou sinéclise) continental estável do Grupo Canastra, o Grupo Araxá é marcado pela sedimentaçăo mais variada e imatura.

Rochas metabásicas ocorrem em todo o pacote, caracterizando um magmatismo toleítico tipicamente continental, com dois conjuntos composicionalmente distintos, de baixo $(<2 \%)$ e alto $p$ 
$2 \%$ ) teores em titânio. Os metabasitos de baixo titânio (BTi) são mais pobres em elementos incompativeis, apresentando padröes de elementos terras-raras (ETR) achatados a pouco diferenciados; os metabasitos de alto titânio (ATi) sło enriquecidos em elementos incompativeis (especialmente $\mathrm{Nb}, \mathrm{Zr}$, $\mathrm{Y} \in \mathrm{Ba}$ ), com padröes mais diferenciados de ETR.

O SCIP é estruturalmente caracterizado como um conjunto imbricado de lentes tectônicas constituída por rochas da sequetencia Serra da Boa Esperança, de seu embasamento e minoritariamente do Grupo Bambui.

Três unidades metassedimentares integram a seqüência Serra da Boa Esperança: provavelmente basal, a unidade Serra da Mamona constitui-se de metaconglomerado quartzitico passando ao topo para uma associação de filito sericítico e quartzítico com grânulos e seixos esparsos, e filitos hematiticos subordinados; a unidade llicinea sobrepóe-se à primeira e é composta predominantemente por ardósia e metassiltito laminado com intercalaçōes decimétricas a métricas de metarenito ortoquartzítico grosso, puro e frequentemente com grânulos bem arredondados; a unidade Serra do Chapadão ocorre tectonicamente destacada das demais e constitui-se de uma alternância de metarenito ortoquartzítico puro a micáceo (bem arredondado e selecionado) e sericitafilito, possivelmente representando uma variação lateral da unidade Ilicinea. Lentes tectônicas do embasamento evidenciam duas associaçóes litológicas: um conjunto de hornblenda gnaisses, denominada de Suite TTG (tonalito-trondjemito-granodiorito), e um conjunto metavulcano-sedimentar, cujas exposiç̄es mais setentrionais constituem o "greenstone-belt de Piumhi". Os hornblenda gnaisses miloníticos da suite TTG são caracterizados litogeoquimicamente por uma gama composicional desde gabrodiotitos até granitos calcialcalinos, predominando os termos intermediários. Isócrona de afloramento (4 pontos) $\mathrm{Rb}-\mathrm{Sr}$ em rocha total, de $2244 \pm 104 \mathrm{Ma}$ (razäo inicial de 0,7015), indica sua idade anterior ao Proterozóico Médio. A associą̧̃o metavulcano-sedimentar inclui metapelitos negros, xistos e filitos máficos e ultramáficos, formação ferrifera bandada e cromititos subordinados.

O embasamento do dominio autóctone é constituído por terreno granito-gnáissicomigmatítico com núcleos subordinados de natureza granito-greenstone. Este domínio integra o embasamento do Cráton São Francisco, na parte oriental da área de estudo, e o Complexo Campos Gerais, na parte meridional. Este embasamento é recoberto discordantemente pelo Grupo Bambui, no qual ora predominam ardósias e metassiltitos (metacalcários subordinados), ora metaconglomerados polimíticos com caracteristicas de leques deltaicos e seixos provenientes das demais unidades mencionadas.

Importante episódio de encurtamento crustal relacionado à Orogênese Brasiliana, por volta de $600 \mathrm{Ma}$, induziu processos de deformaçāo progressiva por cisalhamento de baixo ângulo, resultando na justaposição das três unidades tectônicas acima descritas. Diferenças de nivel crustal nos estágios iniciais da deformaçăo, em condiçőes sinmetamórficas, foram responsáveis pelas diferenças observadas de estilos deformacionais e metamórficos: a NAC, com gradiente metamórfico inverso da fácies xisto verde (zona da biotita) na base à fácies anfibolito no topo, mostra duas geraçōes de dobramento apertado a isoclinal recumbente, ambas com foliaçöes plano-axial penetrativas. Abundantes indicadores cinemáticos, como peixes de mica, foliaçáo $\mathrm{S}-\mathrm{C}$ e lineaçăo de estiramento, indicam transporte tectônico com topo dirigido para leste. No SCIP, o metamorfismo não passa da zona da clorita. A primeira e principal fase de deformaçăo gerou uma foliaçăo penetrativa subparalela ao acamamento sedimentar com raras dobras megascópicas, também com transporte tectônico com topo para leste, com maior grau dispersão nos dados direcionais. No Grupo Bambui, a deformação principal gerou dobras mesoscópicas progressivamente apertadas e deitadas, com a proximidade do conjunto alóctone. Distante do conjunto alóctone as dobras são mais abertas e empinadas, com clivagem ardosiana plano-axial. As rochas do embasamento alóctone, envolvidas neste estágio deformativo, adquiriram foliação milonítica com grau de desenvolvimento heterogêneo e alterações metamórficas compatíveis com a fácies xisto verde inferior.

Duas geraçôes de dobras geralmente abertas e empinadas, pós-metamórficas e sem 
foliação plano-axial, afetaram todo o conjunto após o seu imbricamento tectônico: a mais antiga com eixos com caimento suave para NW e a mais nova (e mais suave) com eixos $\mathrm{N}-\mathrm{S}$. Estas fases deram a estruturação final ao orógeno.

Dataçōes K-Ar, principlmente em mica branca, interpretadas juntamente com os dados preexistentes, indicam que o episódio de deformaçăo principal se deu por volta de $600 \mathrm{Ma}$ durante a Orogênese Brasiliana. Durante tal evento termotectônico, o substrato autóctone não foi termicamente afetado de modo significativo, mostrando idades de resfriamento $\mathrm{K}-\mathrm{Ar}$ (além de idades $\mathrm{Rb}-\mathrm{Sr}$ ) mesoproterozóicas ou mais antigas. Tal contexto caracteriza esta porção da Faixa Brasilia como estruturado por uma tectônica thin skinned, ou seja, por cavalgamentos rasos, com transporte por distâncias superiores a $100 \mathrm{~km}$ para NAC e a $50 \mathrm{~km}$ para SCIP.

Abstract: A tectonic subdivision is proposed for the southern and frontal portion of the Brasilia Fold Belt, based on detailed geologic mapping, compiled and presented on a 1:100,000 scale map. In the studied region, located in SW Minas Gerais State (SE Brazil), crustal shortening was achieved by thinskinned thrusting and folding during Late Proterozoic (ca. $600 \mathrm{Ma}$ ) Brasiliano Cycle. Eastward directed tectonic transport of at least $100 \mathrm{~km}$ is inferred for the thrust sheets now covering the relatively cold and stable southwestern border of the Săo Francisco Craton. Structural style, as well as metamorphic and lithologic characteristics, were used to define three main tectonic units: the uppermost Araxá-Canastra Nappe (ACN), the Ilicinea-Piumhi Thrust System (IPTS), and the Autochthonous Domain.

The Canastra (base) and Araxá (top) Groups, of probable Middle Proterozoic age, comprise the $\mathrm{ACN}$, in which major stratigraphic contacts are subparallel to the basal thrust plane. This nappe is characterized by inverted metamorphic zoning. grading from biotite zone greenschist facies at the bottom, to amphibolite facies, with kyanite-garnet mica schists at the top. Both groups contain intercedded greenschists and amphibolites of magmatic origin (probably dykes and/or minor extrusions), with typical continental tholeitic flood basalt geochemical (including trace and rare earth elements) characteristics. Pelitic schists, with minor carbonatic (and quartzitic) lenses, comprise the lowermost portion of the Canastra Group, followed by interbedded quartzites and phyllites, with quartzitic predominance near the top. Muscovite schists at the top of Canastra Group become progressively rich in feldspar and biotite, grading vertically to the basal paragneisses of the Araxá Group. In contrast to the stable continental shelf (or sag) sedimentation of the Canastra Group, unstable tectonic conditions, with more variable and immature sedimentation, mark the Araxá Group.

The IPTS is composed of numerous thrust slices which splay upwards from a basal thrust plane, including rocks from the Serra da Boa Esperança Sequence, its basement and from the Bambui Group. The Serra da Boa Esperança Sequence, of lower greenschist facies, contains quartzitic metaconglomerates at the base (Serra da Mamona Unit), always in contact with basement rocks. This unit is overlain by metapelites with abundant discontinuous beds of a distinct well sorted, well rounded coarse orthoquartzitic metarenite (llicinea Unit). Similar quartzites interbedded with sericitic phyllites comprise the Serra do Chapadâo Unit, which is tectonically separated from the others. Basement rocks, interleaved by tectonic imbrication comprise an Early Proterozoic or older tonalite-trondjemitegranodiorite suite and a greenstone-belt volcanosedimentary association(mainly black shale, mafic and ultramafic schists, BIF and minor chromitite). A less deformed and more complete exposition of the latter occurs north of the studied area, referred to as the "Piumhi greenstones", with well documented komatiitic lavas containing spinifex textures.

The basement of the Autochthonous domain is a granite-migmatite-gneiss terrain, with minor greenstone-belt type associations and late granitoid intrusions. The Late Proterozoic Bambui Group, lying inconformably on top of the basement, is predominantly composed of slate and metasiltite with subordinated carbonatic rocks, with polymictic metaconglomerates that represent fan delta deposits.

Differences in crustal level, at which syn-metamorphic main (and early) deformation took place, are responsible for differences in structural style and evolution. In the ACN, two generations 
of tight recumbent folding, with axial plane foliations, were developed during the tectonic transport. In the IPTS, low angle shearing formed a penetrative foliation with rare folds which is subparallel to sedimentary contacts. Late stages of the main deformation resulted in open folding of the foliation, truncated by discrete and numerous thrust planes. In the autochtonous Bambui Group, a deformational gradient was established as result of the emplacement of the overlying thrust sheets: flat lying tight folds, with axial-plane slaty cleavage near the thrust contacts grade into upright, more open folds, with steep axial plane slaty cleavage.

Basement rocks, involved in this tectonic imbrication, show mylonitic foliation, specially in gneisses, with overprinting of lower greenschist facies paragenesis.

Two sets of open to gentle, upright post-metamorphic megascopic folds, without axial plane foliation, were developed after the tectonic imbrication: an older one, with NW plunging axes, and a younger one, with $\mathrm{N}-\mathrm{S}$ trending folds.

$\mathrm{K}-\mathrm{Ar}$ age determinations, mainly of white mica of the $\mathrm{ACN}$ and the IPTS metasediments, interpreted in the context of previous data, indicate an approximate age of $600 \mathrm{Ma}$ for the main deformation event. The autochthonous domain was not significantly heated or penetratively deformed during this event.

\section{VLACH, Silvio Roberto Farias}

Geologia e petrologia dos granitoides de Morungaba, SP. 20 de maio. 414p. Orientador: Horstpeter Herberto Gustavo José Ulbrich.

Resumo: Os granitóides de Morungaba (biotita granitos predominantes, dioritos muito subordinados) afloram na região de Morungaba, leste do Estado de São Paulo, por uma área com cerca de $330 \mathrm{~km}^{2}$, ao longo de uma faixa $\left(\sim 15 \times 35 \mathrm{~km}^{2}\right)$ com orientação NNE. São intrusivos em sequiências orto- e parametamórficas de idades meso- a neoproterozóicas da Nappe de Empurrăo Socorro-Guaxupé, ao Sul, e da Faixa Alto Rio Grande, ao Norte. Foram mapeados com critérios faciológicos em escalas $1: 50.000$ e $1: 10.000$.

Sete unidades estatigráficas constituídas por algumas associaçöes petrográficas principais săo reconhecidas e caracterizadas pela suas variabilidades petrográficas e pelos seus mecanismos de colocação. Estas unidades marcam parte importante do magmatismo brasiliano tardi- a pós-orogênico do Cinturāo Itu, no periodo entre 610 e $590( \pm 20) \mathrm{Ma}$, cerca de 10-50 Ma após o magmatismo sinorogênico regional. A primeira associação apresenta em geral fácies equigranulares cinzentas (moderadamente) peraluminosas (biotita \pm muscovita \pm granada \pm ilmenita \pm magnetita), com $\% \mathrm{SiO}_{2}$ entre 70 e 75 , proporçōes constantes entre os minerais félsicos e baixas suscetibilidades magnéticas $\left(k<0,2,10^{-3} \mathrm{emu}\right)$. As outras duas incluem rochas róseas marginalmente peraluminosas (biotita \pm hornblenda \pm titanita \pm magnetita \pm ilmenita \pm allanita \pm muscovita) com $k_{s}$ moderadas a baixas $\left[0,0-2,0\left(.10^{-3}\right) \mathrm{emu}\right]$; em uma delas, a mais félsica $\left(69<\% \mathrm{SiO}_{2}<77\right)$, predominam as rochas equigranulares expandidas; na outra aparecem rochas microporfiriticas, porfiriticas e porfiróides, com $\% \mathrm{SiO}_{2}$ entre 64 e 75 , moderadamente expandidas, cujos termos mais máficos contêm hornblenda.

$\mathrm{Na}$ área setentrional, a unidade mais antiga é o Plúton Areia Branca, com forma irregular a alongada; apresenta corpos concordantes de (leuco) monzogranitos peraluminosos, as fácies mais máficas aflorando em zonas marginais. O Complexo Ouro Verde é formado por inúmeros corpos laminares alongados a curvilaminares NW-W/E-NE ou mais irregulares, intercalados concordantemente com as rochas encaixantes; tem forma irregular a alongada NE-NNE; inclui por um lado, monzogranitos peraluminosos e, pelo outro, quartzo monzodioritos, quartzo monzonitos, monzo- e sienogranitos microporfiriticos e porfiriticos marginalmente peraluminosos, os porfiriticos seguramente mais jovens que o Plúton Areia Branca. As duas unidades mostram estruturas pré-cristalização total, às quais podem se sobrepor deformação plástica variável. Sāo sin- a tardicinemáticas e a sua colocaçăo, ora mais 
permissiva, ora mais forçada, foi controlada por movimentos dextrais na Zona de Cisalhamento Monte Siāo. Para sudoeste aflora o Plúton Jaguari, a unidade mais nova e a maior desta área, alongado na direçăo NNE; sua forma é a de um funil assimétrico, com superposiçăo de diques semi-anelares e corpos irregulares mais jovens. Predominam granodioritos, quartzo monzonitos, monzo- e sienogranitos porfiriticos e porfiróides marginalmente peraluminosos. Os corpos magmáticos sąo discordantes e invadiram sob influência de movimentos dextrais nas zonas de Cisalhamento Monte Sião e CampinasPedreira; os mais antigos se colocaram de modo relativamente mais forçado, os mais jovens de modo mais permissivo, associado à stoping elou abatimento e a zonas transtensionais.

$\mathrm{Na}$ área meridional, as associą̧бes mais antigas são as das Ocorrências Meridionais, formadas por corpos lenticulares a irregulares de leucomonzogranitos peraluminosos, orientados N-S e NNE, e por variedades hibridas, repartidas irregularmente. Estas rochas são, em parte, teto para os plútons meridionais (Plútons Meridional, Oriental e Itatiba) mais jovens e discordantes. Estes últimos contêm monzogranitos, com quartzo monzonitos e sienogranitos subordinados, equigranulares a inequigranulares, marginalmente peraluminosos, e são mais jovens que as rochas mais antigas do Plúton Jaguari, O Plúton Meridional, o principal, tem forma quadrangular irregular a lobada para o sul e mostra típico zoneamento assimétrico e irregular. O Plúton Oriental, com leve zoneamento irregular parcial, é alongado NNE e o Plúton Itatiba, o menor deles, situado a sudeste, apresenta zoneamento concêntrico irregular. Os plútons maiores se colocaram por mecanismos de stoping c subsidência, talvez associados a zonas transtensionais criadas por movimentos sinistrais na Zona de Cisalhamento Campinas-Pedreira.

Os quartzo dioritos e quartzo monzo dioritos, com granulaçōes e texturas variadas. afloram em pequenos corpos irregulares, diques e enclaves, mais associados aos granitóides mais jovens do Plúton Jaguari, aos leucomonzogranitos das Ocorrências Meridionais aos granitóides marginais mais antigos do Plúton Meridional. Nos primeiros casos, rochas de natureza hibrida são comuns. Os principais corpos dioriticos invadiram sincronicamente às atividades magmáticas finais e iniciais nas áreas setentrionais e meridionais, respectivamente. Diques contemporâneos ou pouco mais jovens monzograníticos (predominantes) e dioriticos (subordinados) săo comuns nas áreas centro-oeste e sudoeste (com enxames orientados N-S/NNE e NW, respectivamente). Representam, em grande parte, o final do magmatismo Morungaba e se colocaram em zonas distensivas que cortam as outras unidades, geradas por movimentaçăo sinistral na Zona de Cisalhamento Campinas-Pedreira.

As associą̧ōes porfiriticas săo álcali-cálcicas potássicas, enriquecidas em elementos LIL, com razões LIL/HSF relativamente altas, padrôes fracionados de ETR e anomalias negativas pequenas a moderadas de Eu. Os granitóides meridionais marginalmente peraluminosos apresentam afinidades alcalinas, com teores mais baixos $\mathrm{em} \mathrm{K}$ e algo mais elevados em $\mathrm{Na}$; o fracionamento dos ETR é mais moderado e as anomalias de Eu são mais marcadas. Parte das variedades ocidentais mais félsicas do Plúton Jaguari thes são similares. Em cada associação, as rochas progressivamente mais máficas são mais ricas em elementos LIL e ETR, com anomalias negativas menos expressivas de Eu. Os monzogranitos peraluminosos apresentam fracionamento moderado de ETR $\mathrm{e}$ anomalias negativas acentuadas de Eu. Os quartzo monzo dioritos têm similaridades quimicas com os granitóides potássicos.

A evolução magmática nas principais unidades resulta da combinaçăo de mecanismos de ascenção e colocaçăo de magmas e de cristalização fracionada modal e năo modal, destacando-se os mecanismos de mistura e/ou desmistura entre liquidos e sólidos, diferenciação por fluxo e cristalizaçăo in situ. As variedades hibridas săo originadas através da mistura de magmas e/ou de mushes dioríticos e graníticos diferenciados.

A cristalizaçẫo final dos magmas de Morungaba ocorreu sob pressốes litostáticas entre 2,0 e 3,0 Kbar. As rochas dioriticas e as graniticas marginalmente peraluminosas foram formadas em ambientes oxidantes, com $\Delta_{\mathrm{NNO}(740)} \sim 2,0(+1,0-0,5)$, com progressivo aumento da $f_{\mathrm{O}_{2}}$ e da $f_{\mathrm{H}_{2} \mathrm{O}} \mathrm{com}$ a diminuiçăo da temperatura. Os monzogranitos peraluminosos representam ambientes mais redutores, com $\Delta_{\mathrm{NNO}(670)}-0,0( \pm 1,0)$, a $f_{\mathrm{H}_{2} \mathrm{O}}$ também aumentando nas rochas mais félsicas. As temperaturas de 
saturação para $\mathrm{Zr}$ sugerem magmas parentais predominantemente liquidus. Nas rochas graniticas, as relaçoes entre a $f_{\mathrm{H}_{2} \mathrm{O}}$ e a $f_{\mathrm{HF}}$ se mantiveram no intervalo entre $10^{3,2} \mathrm{e} 10^{4,0}$.

As caracteristicas geoquímicas destas rochas refletem a combinação de fatores herdados das rochas-fonte e adquiridos durante a geraçăo e a cristalizaçăo dos respectivos magmas.

A gènese dos magmas das rochas potássicas e alcalinas é relacionado a um evento maior de underplating, formado por injeçōes sucessivas de magmas básico-intermediários oxidados, provenientes de manto litosférico heterogêneo, com diferentes graus de enriquecimento e evoluçäo isotópica. A fusła da parte menos enriquecida deste manto, gerou o magmatismo dioritico de Morungaba, com razöes $\left({ }^{87} \mathrm{Sr} /{ }^{86} \mathrm{Sr}\right)_{0}$ entre 0,7060 e 0,707 e $\varepsilon_{\mathrm{Nd}(C H U R)}-12,5$. As associações petrograficas alcalinas $\left[\left({ }^{87} \mathrm{Sr} /{ }^{86} \mathrm{Sr}\right)_{0}\right.$ entre $0,7060-0,707 ; \varepsilon_{\text {Nd(CHUR) }}$ entre $-13,0$ e $\left.-10,0\right]$ derivam de fontes infracrustais igneas $\mathrm{em}$ fácies granulito, submetidas à fusão por influência destes magmas dioriticos. As rochas potássicas $\left({ }^{87} \mathrm{Sr} /{ }^{86} \mathrm{Sr}\right)_{0}$ entre 0,7070 e 0,$7080 ; \varepsilon_{\mathrm{Nd} C \mathrm{CHUR}}$ ) entre $\left.-14,0 \mathrm{e}-13,0\right)$ são, provavelmete, originadas da cristalizaçăo de magmas básico-intermediários pouco mais antigos e algo mais evoluidos isotopicamente, contaminados por materiais igneos infracrustais. As associaçōes petrográficas peraluminosas foram derivadas a partir de magmas gerados em ambientes cata- a mesozonais (fáceis anfibolito) por fusào parcial de sequências (leuco) metatonaliticas a metagranodioriticas.

As idades modelo $\mathrm{Sm} / \mathrm{Nd}$ sugerem diferentes eventos de reorganizaçăo geoquimica na litosfera. Postula-se, em uma primeira etapa, a formação de crosta tonalítica-granodiorítica, a rochafonte para as fáceis peraluminosas (há cerca de $2,3 \mathrm{Ga}$ ). Uma segunda etapa, mais jovem $(\sim 2,0 \mathrm{Ga})$, seria marcada por extenso underplating básico-intermediário, que teria gerado os materiais-fonte para as rochas alcalinas, com paralelo (?) enriquecimento do manto litosférico em elementos LIL. Este manto, heterogeneamente enriquecido, foi a fonte predominante para as rochas dioriticas $e$ teve participaçäo significativa na gênese dos granitóides potássicos.

O magmatismo álcali-cálcico e a sua passagem para o magmatismo alcalino macariam, respectivamente, uma transiç̧o relativamente rápida entre os periodos sin- a tardiorogènico e tardi- a pós-orogênico na região leste do Estado de São Paulo. Estes fenômenos são interpretados como respostas à evolução do manto litosférico e consequente estiramento litosférico regional, provocando a fusão de materiais-fontes progressivamente menos férteis.

Abstract: The Morungaba granitoids crop out in the Moningaba region, eastern part of the State of São Paulo, southeastern Brazil, as an irregular-elongated NNE belt (appr. 15x35 km²), covering about $330 \mathrm{~km}^{2}$. The rocks intruded into Meso- to Neoproterozoic ortho- and parametamorphic sequences belonging, in the southern area, to the Socorro-Guaxupe Nappe and, to the north, to the Rio Grande Belt. Detailed mapping was performed using 1:50.000 and 1:10.000 scales.

Seven intrusive stratigraphic units were recognized, constituted by some petrographic associations, each with distinct petrographic ranges and intrusion styles. The units are important constituents of the late- to postorogenic Brasiliano magmatism of the regional granitoid Itu Belt, with intrusion ages around 610 to $590( \pm 20) \mathrm{Ma}$, postdating by about 10 to $50 \mathrm{Ma}$ the earlier sinorogenic events. The first associatuion presents grey equigranular, moderately peraluminous, granitoids (with biotite \pm muscovite \pm garnet \pm ilmenite \pm magnetite), with a $\mathrm{SiO}_{2}$ range of $70-75 \%$, little variation in proportions of felsic minerals, and low magnetic susceptibilities $\left(\mathrm{k}<0,2,10^{-3} \mathrm{emu}\right)$. The other two associations, include mostly pink, metaluminous to peraluminous (marginally peraluminous) granitoids (with biotite \pm hornblende \pm sphene \pm magnetite \pm ilmenite \pm allanite \pm muscovite), both showing low to moderate $\mathrm{k}$ values $\left[0,0-2,0\left(.10^{-3} \mathrm{emu}\right)\right]$; one of them, mostly with equigranular, more felsic varieties $\left(\mathrm{SiO}_{2}\right.$ about $\left.69-77 \%\right)$, shows little modal variation, while the other is mainly constituted by more varied, microporphyritic to porphyroid granitoids $\left(\mathrm{SiO}_{2}\right.$ between $\left.64-75 \%\right)$ with hornblende present in the more mafic members.

In the northern area, the oldest units is the Areia Branca Pluton, irregular to elongated, 
made up of concordant intrusions of zoned peraluminous leucomonzogranites (more mafic facies located at the outside). The Ouro Verde Complex, also irregular to elongated to the NE-NNE, presents many elongated granitic laminar bodies (oriented NW-W to E-NE) concordantly interleaved with country rocks; the granites of the complex are, on the one hand, peraluminous monzogranites and on the other hand an assorted set of marginally peraluminous granitoids (quartz monzodiorites and monzonites; monzo- and syenogranites); the last set is younger than the rocks of the Areia Branca pluton. Both the cited units present pre-crystallization structures, sometimes overprinted by later plastic deformation; they intruded in a sin- to latekinematic ("forceful" to "permissive") regime and their emplacement was apparently controlled by dextral movements of the Monte Sião shear-zone. To the SW of these units, the Jaguari Pluton is found, the youngest and largest intrusion in this area, clongated to the NNE. The pluton shows the form of an asymmetric funnel, cut by ring dikes and irregular bodies. Its main granitoids are marginally peraluminous porphyritic to porphyroid granodiorites, quartz monzonites and monzo- and syenogranites. The individual bodies are discordant and were emplaced on account of dextral displacement of the Monte Sião and Campinas-Pedreira shear zones, the carliest ones under the influence of more forceful regime, the youngest ones more permissively with several evidences of marginal stoping and local or regional block foundering.

In the southern region, the oldest association are that present in the Southern Occurrences, made up of lenticular to irregular bodies, oriented N-S to NNE, of peraluminous leucomonzogranites and hybrid rocks, the last ones with more irregular distribution. These rocks are in part roof rocks for the younger and discordant southern intrusions (Meridional, Oriental and Itatiba Plutons). These plutons are constituted by predominant monzogranites, with subordinate quartz monzonites and syenogranites, marginally peraluminous, equigranular to inequigranular rocks, and younger that the older rocks of the Jaguari Pluton. The main occurrence is the Meridional Pluton, with a squarish to irregular outline and southern lobate projections; it shows irregular to asymmetric zonation. The slightly zoned Oriental Pluton is somewhat elongated to the NNE, while the Itatiba occurrence, also showing a concentric zoning, is the smallest of the three. The largest pluton of this area invaded permissively by means of stoping and subsidence of country rocks, perhaps related to transtensional zones created by sinistral movements of the Campinas-Pedreira shear zone.

Quartz diorites and quartz monzodiorites, presenting varying grain sizes and textures, are observed as enclaves, dikes and smaller irregular occurrences, more so in the younger granitoids of the Jaguari Pluton, within the leucomonzogranites of the Southern Occurrences (where hybrid rocks are common), and in the older border granitoids of the Meridional Pluton. The main diorite occurrences are contemporaneous with the initial southern magmatic intrusions and with the waning stages of the northern magmatism. Contemporaneous or somewhat younger monzogranitic predominant and subordinate dioritic dike swarms are frequently observed in the central-western and SW parts of the district, respectively oriented to the N-S/NNE and to the NW. They represent the last events of the Morungaba magmatism ad were emplaced within extensional fractures created by sinistral movement of the Campinas-Pedreira shear zone.

All porphyritic rocks associations are alkali-calcic, potassic, with enrichment in LIL elements ad relatively high LIL/HFS elemental ratios, also showing fractionated REE patterns and small to moderate negative Eu anomalies. The marginally peraluminous southern granitoids present alkaline affinities, with lower $\mathrm{K}$ and higher Na values; REE fractionation is moderate, with increased negative Eu anomalies. Some of the more felsic facies of the Jaguari Pluton are chemically similar. In each rock association, the more mafic members are more REE enriched, with lesser marked Eu anomalies. The quartz diorites are chemically similar to the potassic granitoids.

Magmatic evolution in the principal units results from a combination of several mechanisms, involving ascent and emplacement of magmas together with fractional (modal and nonmodal) crystallization. The hybrid facies form by mixing of dioritic and differentiated granitic magmas or mushes. 
The final crystallization of the Morungaba magmas took place under pressures of 2 to 3 kbar. The diorites and the marginally peraluminous granites crystallized in an oxidizing environment, at $(\Delta)_{\mathrm{NNO}(740)}=2,0(+1,0,-0,5)$, with a progressive increase in $f_{2}$ and $f_{\mathrm{H}_{2} \mathrm{O}}$ as temperature decreased. The peraluminous monzogranites were formed under more reducing conditions $\left.\Delta_{\mathrm{NNO}(670)}=0 \pm 1\right)$, the Areia Branca Pluton showing decreasing $f_{2}$ in the more felsic rocks. The $\mathrm{Zr}$ saturation temperatures suggest that the corresponding magmas were probably largely liquid. In the granites, the $f_{\mathrm{H}_{2} \mathrm{O} / \mathrm{H}_{2} \mathrm{O}}$ ratios remained between $10^{3,2}$ and $10^{4,0}$.

The main geochemical features of these rocks area combination of original source characteristics and those acquired during the melting episode and subsequent evolution.

The generation of the more potassic and alkaline magmas is attributed to a major underplating event caused by successive intrusions of oxidized basic-intermediate magma, released from a heterogeneous lithospheric mantle showing different degrees of enrichment and of isotopic evolution. The less enriched portion of this mantle $\left({ }^{87} \mathrm{Sr} /{ }^{86} \mathrm{Sr}\right.$ between 0,7060 and 0,$\left.7070 ; \varepsilon_{\mathrm{Nd}(\mathrm{CHUR})}-12,5\right)$ was the source for the dioritic magmatism. The alkaline associations were derived from lower crustal granulitic layers of igneous origin $\left[\left({ }^{87} \mathrm{Sr} /{ }^{86} \mathrm{Sr}\right)_{0}\right.$ between 0,$7070 ; \varepsilon_{\mathrm{Nd}(\mathrm{CHUR})}$ between -13 and -10$]$, during a melting episode triggered by the basic-intermediate magmas. The potassic rocks $\left[\left({ }^{87} \mathrm{Sr} /{ }^{86} \mathrm{Sr}\right)_{0}\right.$ between 0,7070 and 0,$7080 ; \varepsilon_{\mathrm{ND} \text { (CHUR) }}$ between -14 and -13$]$ were probably formed by crystallization of somewhat earlier and isotopically evolved basic-intermediate magmas, contaminated by crustal material. The peraluminous associations were generated by melting of amphibolite-facies cata- to mesozonal crustal igneous rocks, representing the metamorphic equivalents of tonalites and granodiorites.

The Sm/Nd model ages indicate at least two events of lithospheric geochemical reorganization. At about $2,3 \mathrm{Ga}$, a tonalitic-granodioritic crust was formed, later on converted into the source rocks for the peraluminous Morungaba granites. A second stage occurred at about $2,0 \mathrm{Ga}$, with extensive underplating by basic-intermediate materials and simultaneous enrichment of the lithospheric mantle in LIL elements, which was the main source rocks for the alkaline and (in part) the potassic Morungaba sequences.

The alkali-calcic Morungaba magmatism marks the transition between the sin- to lateorogenic stages, and the alkaline granite intrusions determine the postorogenic Brasiliano phase in the eastern State of São Paulo. These geologic phenomena are interpreted as a response to the evolution of the lithospheric mantle, coupled with a regional lithospheric stretching and melting of progressively less fertile source rocks.

\section{ZAMPEER, Valdir Aparecido}

Cimento portland aditivado com pozolanas de argilas calcinadas: fabricação, hidratação e desempenho mecanico. 14 de outubro. 233p. Orientador: Yushiro Kihara.

Resumo: O uso adequado de pozolanas de boa qualidade possibilita a produçăo de cimentos especiais, de menor custo de fabricação $\mathrm{c}$ de maior durabilidade que os correspondentes sem adição. $\mathrm{O}$ emprego de pozolanas proporciona, adicionalmente, ganhos significativos em termos de produtividade e uma extensão da vida útil dos equipamentos de produção e do próprio jazimento calcário.

A diversidade de caracteristicas e desempenhos das pozolanas dificulta sobremaneira a seleção e qualificação dos diversos materiais disponiveis.

Face às limitações dos métodos tradicionais de determinaçăo da "atividade pozolânica", propōe-se uma metodologia alternativa, na qual as pozolanas såo investigadas sob diferentes conteúdos de $\mathrm{Ca}(\mathrm{OH})_{2}$. A metodologia proposta proporciona uma melhor definição da qualidade e desempenho da pozolana e, paralelamente, o conhecimento da exata proporção de hidróxido de cálcio qua a mesma fixa após um determinado período de reação. 
No que se refere à evolução da resistência mecânica, verifica-se que o desempenho dos cimentos aditivados com pozolanas de argila é variável e grandemente dependente das caracteristicas da pozolana, do teor da adiçåo e do tempo de cura considerado.

Os cimentos de melhor evolução de resistência foram obtidos com as pozolanas mais reativas (de rápida reação) e que desenvolvem produtos de reação de grande capacidade cimentícia. As argilas calcinadas que apresentam elevados teores de quartzo $(>30 \%)$ e demandam maior quantidade de água são de desempenho inferior. Constata-se, por outro lado, que a resistência dos cimentos aditivados não cresce linearmente com a capacidade de fixação de hidróxido da pozolana.

As pozolanas de argila de grande capacidade de fixação de $\mathrm{Ca}(\mathrm{OH})_{2}$ são particularmente adequadas para aquelas situą̧ōes onde se requer pastas com a menor basicidade possivel. Quando adicionadas em elevadas proporções (acima de $40 \%$ ), todavia, a parcela de clínquer do cimento não produz hidróxito suficiente para a completa reaçăo dessas pozolanas, verificando-se, nestes casos, uma sensivel redução nos valores de resistência mecânica dos cimentos.

Embora em geral năo utilizadas pela indústria cimenteira, as argilas que originalmente exibem uma certa quantidade de carbonatos associados podem proporcionar pozolanas de excelente desempenho. A queima necessária à ativação dos argilominerias $\left(700-800^{\circ} \mathrm{C}\right)$ promove uma descarbonataçẫo parcial dos carbonatos e a geraçẫo simultânea de fases hidraulicamente ativas ("protoclinquer"). Obtém-se, como consequêencia, uma pozolana de maior reatividade e que proporciona cimentos de melhor evolução de resistência nas idades iniciais. O menor requerimento de $\mathrm{Ca}(\mathrm{OH})_{2}$ das mesmas, face ao caráter pouco mais básico, permite que sejam adicionadas em elevadas proporçōes (até $50-60 \%$ ), sem que se esgote o hidróxido liberado pelo clínquer. Mesmo nessas proporçōes, a resistência pode superar o limite de $32 \mathrm{MPa}$ imposto por norma.

As caracteristicas mineralógicas e composicionais dos clinqueres também influenciam o desempenho mecânico dos cimentos aditivados. As influências do clinquer sâo entretanto menos expressivas que aquelas decorrentes das alteraçôes na constituiçăo, reatividade e teor da adição pozolânica.

Idealmente, o clinquer empregado na produção de cimentos com pozolanas deve exibir um elevado teor de alita (65-70\%), ser constituído de cristais pequenos e reativos (dimensalo média próxima de $30 \mu \mathrm{m}$ ) e, adicionalmente, mostrar uma relaçåo $\mathrm{C}_{3} \mathrm{~A} / \mathrm{C}_{4} \mathrm{AF}$ superior a 1 .

Abstract: The proper use of good quality pozzolans assures the production of special cements of lower manufacturing costs and higher durability than the corresponding cement without pozzolan. In addition, the use of allows significant productivity gain and also increases the useful life of equipments and limestone deposits.

However, the different characteristics and performance of pozzolans raise difficulties for the adequate selection and qualification of the available materials.

In view of the inaccuracy of the traditional "pozzolanic activity" determination methods, an alternative methodology is proposed, whereby the pozzolans are investigated under different contents of calcium hydroxide. The proposed methodology outlines a better prediction of the pozzolan quality and performance and permits, at the same time, the knowledge of the correct proportion of calcium hydroxide combined by the pozzolan, after a given reaction period.

Regarding the mechanical strength evolution, it has been found that cements added with clay pozzolans have a variable performance, which is influenced by the pozzolan characteristics, the admixture content and the curing time.

Cements with the best strength evolution were obtained from reactive pozzolans, which usually develop reaction products of a high binding capacity. Burned clays which have a high content of quartz $(>30 \%)$ and require a greater quantity of water show a poorer performance. On the other hand, it is realized that cements with pozzolanic admixtures do not show a linear increase of the strength with the hydroxide combining capacity of the employed pozzolan. 
Clay pozzolans with great $\mathrm{Ca}(\mathrm{OH})_{2}$ combining capacity are particularly suitable to situations where pastes with a minimum basicity are required. However, when such pozzolans are added in large quantities (over $40 \%$ ), the remaining clinker does not produce enough hydroxide for the complete reaction of the pozzolan, in which case the mechanical strength of the cements undergoes a substantial reduction.

Although in general not used by the cement industry, clays which originally show a certain amount of associated carbonates can produce pozzolans of excellent performance. The burning required for the activation of clay minerals $\left(700-800^{\circ} \mathrm{C}\right)$ causes a partial decomposition of the carbonates and a simultaneous generation of hydraulically active ("protoclinker"). As a consequence, a pozzolan of higher reactivity is obtained which allows the manufacturing of cements of better strength evolution at earlier ages. The smaller requirement of $\mathrm{Ca}(\mathrm{OH})_{2}$, in view of its more basic nature, allows the addition of high percentages (up to $50-60 \%$ ) of such pozzolans, without exhausting the hydroxide released by the clinker. Even with such contents, the strength after 28 days reaction can exceed the limit of $32 \mathrm{MPa}$ dictated by brazilian standards.

The mineralogical and compositional characteristics of the clinker also affect the mechanical performance of the blended cements. The effects of clinker alterations are however less expressive than those derived from changes in composition, reactivity and content of pozzolanic admixture.

Ideally, the clinker used for the production of pozzolan blended cements should exhibit a high content of alite $(65-70 \%)$, should consist of small and reactive (with average dimensions of approximately $30 \mu \mathrm{m}$ ) and should also show a $\mathrm{C}_{3} \mathrm{~A} / \mathrm{C}_{4} \mathrm{AF}$ ratio greater than 1. 